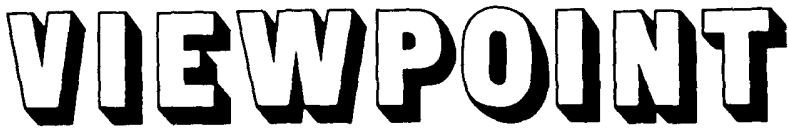

\section{Industry's Role in Rangeland Restoration}

\section{MICHAEL J. CWIK}

Will government determine the future of our rangelands? It is currently confronted by overlapping rangeland-oriented demands from ecologists, stockmen, and industry. Polycentric organizations, motivated by ecological interest groups such as the Sierra Club, Audubon Society, and the Izaak Walton League, demand that government give increasing emphasis to environmental considerations in industrial development. Government is also faced with demands from livestock interests trying to maintain themselves in the crossfire of a tight economy, increased demand for meat protein, and an awareness toward energy efficiency in agriculture. Finally, government is faced with demands from industry to be reasonable in establishing environmental guidelines which have to be met as a prerequisite for continued construction or operation of new facilities.

Government has failed in many instances to adequately cope with ecological and livestock interests in its philosophy on environmental impact assessments. Rather, it assumes an industry-oriented policy posture which encourages industrial development regardless of environmental consequence. At the Western Governors' Conference held in Albuquerque, New Mexico, last August the Phoenix Gazette quoted Governor John Vanderhoof of Colorado as saying,

We're not going to be run roughshod over by bureaucrats and people from high levels in Washington in the develop-

The author is an ecologist with Dames \& Moore in Phoenix, Arizona $\mathbf{8 5 0 0 4 .}$ ment of these resources unless the tradeoffs and the accommodations of our people are properly madc.

Among tradeoffs listed at the conference as necessary for western industrial expansion to proceed are:

1) Federal loans and grants to pay for water and sewer projects, schools, and other facilities that will be needed to handle an influx of population.

2) Doubling of the state's share of royalties paid to private firms for the extraction of resources under federal lease, from the current $37.5 \%$ to $66-2 / 3 \%$.

3) Relative independence from federal rules and regulations in planning orderly development of the coal and shale fields.

This philosophy of trading environmental protection for economic expediency is primarily what environmentally aware citizens face in trying to implement environmentally sound land use policies.

\section{Industrial Interests}

Industry's interest in rangelands results from a historical chain of events culminating in what has popularly been termed the energy shortage. Energy consumed in the U.S. has grown steadily and has increased approximately 18 -fold in the last century. Today, with $6 \%$ of the world population, the U.S. accounts for over $35 \%$ of the world energy consumption. Annual energy consumption for the U.S. in 1972 was $71.5 \times 10^{15}$ British thermal units (Btu). Oil, natural gas, and coal comprised the bulk of our consumption of primary energy fuels (Table 1). Domestic sources contribute approximately $84 \%$ of the resource base from which our primary energy comes. By 1985 the National Petroleum Council projects an increase in our total energy consumption rate of $43 \%$ to $125 \times 10^{15}$ Btu's.

At present, use of electricity is emphasized as a principal energy source in the United States, particularly in light of declining supplies of petroleum and natural gas. Electrical energy supply can fall short of demand if facilities to convert primary energy, mainly coal and nuclear materials, to electricity are not available in sufficient quantity. Consequently, emphasis is being placed on development of facilities for generating electricity from coal or nuclear materials. In the case of nuclear power plants, it has been projected that between 1980 and 1990 , sites for 17 new $1000 \mathrm{Mw}$ nuclear units will be needed each year along with an annual requirement of 10,000 miles of accompanying transmission lines. Much of this expansion is materializing in the western states, as a result of demands from burgeoning metropolitan areas. Site investigations for power plants in our western states often point to rangelands as

Table 1. Sources of energy fuels consumed in the U.S. in 1972.*

\begin{tabular}{lc}
\hline Fuel & \\
\hline Oil & $44.4 \%$ \\
Natural gas & $31.8 \%$ \\
Coal & $18.6 \%$ \\
Hydro & $4.1 \%$ \\
Nuclear & $1.0 \%$ \\
Electricity & generated from \\
& the above, con- \\
& suming $25 \%$ of \\
& this total energy. \\
\hline
\end{tabular}

*British Petroleum Co., 1972, Statistical review of the world oil industry. 
offering preferable inland areas for localized and linear industrial development. Rangelands are also important to industry because many are underlain by extensive tracts of coal reserves, one of the major primary energy fuels. Northeastern Arizona and New Mexico, northern Colorado, Wyoming, and southeastern Montana all have extensive proven coal reserves.

Industry's record regarding the rangeland environment has not generally been compatible with the interests of environmentalists and stockmen. Evidence points to the seeming disinterest by industry to take a holistic approach in its industrial expansion process. One needs only to point out the paucity of water resources which will be overcommitted in our western states if all proposed coal mining, oil shale development, and energy conversion facilities become a reality. Further, possible socio-economic repercussions to land use in natural areas have historically been given low priority when plans are proposed for large industrial facilities located in rural areas. The disregard for the major role of unquantified or unquantifiable factors in sightselection processes have exemplified industry's inability to consider the long-term cumulative environmental impact on industrial expansion into relatively undeveloped areas. Industry's interest in rangeland per se is practically nonexistent. Rather, industry looks with interest at the land surface and subsurface on which rangelands exist.

\section{Opportunity to Benefit}

Can rangelands benefit from industrial development? The legislative process is now open for ecological, livestock, and industrial groups, to seek ways by which their particular interests can be protected.

\section{Environmental Legislation}

Certain ideas involving environmental issues which can affect the future of rangelands are being advanced. These ideas result from a plethora of court cases involving environmental issues and recent federal, state, and local legislation and recommendations.

On the federal level, the Council on Environmental Quality (CEQ), in their recently revised Guidelines for Environmental Reports, is initiating several new approaches in preparation of environmental impact statements. Section 1500.2 in the Code of Federal Regulation reads in part,

as early as possible and in all cases prior to agency decisions concerning recommendations or favorable reports on pro- posals ... federal agencies will, in consultation with other appropriate federal, state, and local agencies of the public, assess in detail the potential environmental impact.

Section 1500.8 goes on to say, in part that,

the interrelationships and cumulative environmental impacts of the proposed actions ... shall be presented in the statement.

Further on, Section 1500.8 states,

Agencies should also take care to ... determine secondary population and growth inpacts resulting from the proposed actions and its alternatives ....

Part (2) of Section 1500.8 in the revised $C E Q$ guidelines goes on to say in part that, among the points to be covered in environmental statements, is,

the relationship of the proposed action to land use plans, policies and controls for the affected area. This requires a discussion of how the proposed action may conform or conflict with the objectives and specific terms of approved or proposed federal, state, and local land use plans, policies and controls, ....

These guidelines clearly indicate the federal government's philosophy in assessing potential environmental impact. Emphasis on estimating cumulative impact, estimating indirect impact from increased population pressures, and relating these impacts to any land use patterns in the area prior to any decisions for industrial development in an area, is a fresh approach in the environmental impact assessment process.

Associated with the revised CEQ guidelines are federal, state, and local environmental-oriented actions. On the national level, the Bureau of Reclamation has publicly taken a stand opposing the White House energy plans in western states. The Bureau believes that the possibility of augmenting energy production is severely restricted by a crisis resulting from impending water shortages. Environmental legislation and regulations from Washington have recently occurred. The U.S. Surface Mine Reclamation Act of 1973 requires that all mine areas be revegetated within 2 years of abandonment. Although this act is unrealistic in its time schedule for revegetation, it is a start in the right direction. The House and Senate have recently agreed to finance a land reclamation fund with a 35 cents/ton fee on all coal mined in the U.S. Most of the revenue from this plan would go to restoring land scarred by abandoned strip mines.

\section{Industry's Responsibility}

This author urges that industry play a significant role in improving conditions of western rangelands which are directly or indirectly involved in proposed industrial development. Industry, due to either voluntary or involuntary ignorance, will not take the initiative in improving these rangelands. It must be guided by legislation developed from objective scientific evaluation. Why should industry not restore indirectly impacted rangelands to their highest biological potential?

At the site of Fermi National Accelerator Laboratory near Batavia, Illinois, plans are under way to restore the lush tall grass prairie in a 900-acre area surrounding the industrial site. This would, when completed, be the nation's largest reconstructed prairie. If maintained with proper grazing and management, beef production would be increased while an example of a major grassland ecosystem would be available for study by ecological interests.

Ecological interests, livestock interests, industrial interests and especially government, should all take notice of this action. Industry has benefited. By showing a positive, action-impelling environmental awareness of the importance of our nation's rangelands, it has won support from some of those interests it spends precious time and money on in arbitration procedures. Industrial environmental awareness such as this, motivated by careful legislation and implemented for all industrial activity on rangelands, can restore at least a small portion of the rangeland environment in our country at a time when ecological and livestock interests justifiably point to its degradation, and agronomists emphasize its future importance for finishing livestock. Certainly, in our day and age, when several hundred million dollars are commonly budgeted for major industrial developments such as electric generating facilities and accompanying equipment for preventing air and water contamination, a small fraction of $1 \%$ of this budget can be dedicated to improvement of biological systems, such as rangelands, which lie immediate to these facilities.

In summary, legislation has finally provided some opportunities whereby rangelands can benefit from industrial development. Ecological, livestock, and industrial interests, aided by sound scientific consultation, should seize these opportunities and insist that sound mitigating measures be employed and supervised to restore impacted rangelands to their full biological potential. 